\title{
AHMAD IBN TULUN E SEUS HERDEIROS: O PRIMEIRO EMIRADO AUTÔNOMO DO EGITO, 868-905
}

\author{
Ahmad Ibn Tulun and his heirs: The first Egypt's \\ autonomous emirate, 868-905
}

José Henrique Rollo*

\begin{abstract}
RESUMO
Entre 869-905, o Egito, que, desde 641, era uma província do califado, foi governado por uma dinastia de origem turca que escapou ao controle do Estado Abássida. Esse processo não é mencionado em detalhes mesmo nos livros sobre o Oriente Médio na Idade Média. Ele é apresentado, de um modo geral, como episódico e sem consequências de longa duração. Este artigo intenta explanar alguns aspectos dos acontecimentos e sugerir alguns de seus efeitos sobre a história do Egito.

Palavras-chave: califado abássida; Egito Medieval; soldados turcos; Ibn Tulun; tulúnidas.
\end{abstract}

\begin{abstract}
Between 869-905, the Egypt that since 641 was a province of the Caliphate, experienced an attempt to build an emirate ruled by a dynasty of Turkish origin that was not controlled by the Abbasid State. This process is not mentioned in details even by books about the Middle East in the Middle Ages. It is usually presented as anecdotic and without long-terms consequences. This article aims to expose some aspects of the events and to suggest some of their effects over Egypt's history.
\end{abstract}

Keywords: Abbasid Caliphate; Medieval Egypt; Turkish soldiers; Ibn Tulun; Tulunids.

"Professor dos Cursos de História e de Comunicação e Multimeios e pesquisador do Laboratório de Estudos Americanos, Africanos e Orientais (LEAAO) e do Laboratório de Arqueologia, Etnologia e Etno-História (Tulha) da Universidade Estadual de Maringá. 


\section{Introdução ${ }^{1}$}

O surgimento, no decorrer do século IX, de emirados que, apesar das alegações de fidelidade de seus dirigentes ao califa, eram efetivamente autônomos, foi um dos fatores que atestaram as dificuldades do Estado Abássida sediado em Bagdá de se reproduzir como império a partir de um certo âmbito de expansão geográfica. Em seu auge, na segunda metade do século VIII, ele se estendia da Espanha ao norte da Índia e à Ásia Central. Eram mais de nove mil quilômetros de distância entre o extremo-leste e o extremo-oeste. Não havia recursos comunicacionais, militares e financeiros suficientes para um controle eficaz de populações muito diversificadas em termos de perfis étnicos, memórias coletivas, tradições guerreiras e relações com o mundo circundante. Não bastava ter forças armadas leais. Era preciso fazê-las crescer o tempo todo e garantir seu abastecimento, pagamento e capacidade de deslocamento. Também era preciso assegurar a viscosidade dos mecanismos de incorporação de setores locais que vislumbrassem vantagens em aderir à ordem político-administrativa abássida. Isso sem falar das contínuas e lacerantes tensões entre xiitas, sunitas e outros grupos sectários. Não admira, portanto, o crescimento das rebeliões e das iniciativas por autonomia nos séculos IX e X. ${ }^{2}$

Este artigo trata de uma faceta desse processo de fragmentação do império abássida. Ele remete a um lugar e uma época que raramente mereceram mais do que um ou dois parágrafos nos compêndios de história do Oriente Médio (para alguns, Oriente Próximo): o Egito no século IX e na primeira metade do século X. Assim, considerando que suas intenções são meramente didáticas, evitou-se paramentá-lo com um aparato erudito e as referências bibliográficas são todas de fácil acesso. $O$ foco recai sobre as ações de um administrador provincial de origem turca, Ahmad Ibn Tulun, e de seus herdeiros, que ensaiaram e, por algum tempo, efetivamente conseguiram construir sua própria dinastia dirigente. O objetivo central é

1 Uma observação: como não temos regras mínimas bem definidas de transliteração de nomes próprios árabes e turcos para a língua portuguesa, optei nesse texto - que se funda em obras de divulgação feitas no Ocidente - pela mera simplificação (retirando os acentos e as marcas fonéticas, por exemplo) dos nomes, tomando por base os usos consagrados em inglês e francês.

2 STAVRIANOS, L. S. A Global History: From Prehistory to the Present. Englewood Cliffs: Prentice-Hall, 1995, p. 186-187; SOURDEL, D. Histoire des Arabes. Paris: P.U.F., 1976, cap. IV. 
apresentar uma síntese do período, enfatizando um conjunto de processos políticos nele desencadeados que tiveram desdobramentos de longuíssima duração, afetando a história do país até o século XIX: a presença contínua de elites dirigentes estrangeiras a governar uma população de fala predominantemente árabe, que não compartilhava de suas tradições, e que, com muita frequência, mantinha com elas divergências importantes no interior do Islã. Tais divergências - mais ou menos acentuadas a depender da conduta dos administradores provinciais - eram particularmente significativas considerando-se o forte senso de pertencimento e continuidade que a população local mantinha com o vale e o delta do Nilo. ${ }^{3}$

\section{Conquista e transformação do Egito em província do Califado}

Entre finais de 639, quando tropas muçulmanas partiram da Síria, atravessaram o Sinai e penetraram em seu território, e 646, ano em que Alexandria, a mais importante cidade do país, foi definitivamente controlada, o Egito foi tomado aos bizantinos e incorporado como província do Califado, que estava sediado em Medina, no oeste da Península Arábica. Historiadores de diferentes matizes parecem concordar que foi uma conquista pouco violenta e apoiada por significativa parcela da população local, farta das perseguições religiosas aos coptas, que eram cristãos, mas divergiam da linha cristológica adotada pela Igreja Grega, dos desmandos dos administradores e dos impostos escorchantes cobrados por Bizâncio. ${ }^{4}$ Ademais, em virtude das guerras entre persas e bizantinos (de 619 a 629), o Egito, transformado em campo de batalhas, viu a produção agrícola declinar e os trabalhadores abandonarem os campos. Mercadores, artesãos e camponeses desejavam,

3 GOLDSCHMIDT, Jr., A.; JOHNSTON, R. Historical Dictionary of Egypt. $3^{\text {rd }}$ edition. Lanham, Maryland, and Oxford: Scarecrow, 2003; MARCOU, J. L'Egypte Contemporaine. Paris: Le Cavalier Bleu, 2008.

4 Dados breves em HUGONIOT, C. Quand l'Afrique du Nord était chrétienne. L'Histoire, v. 321, p. 62-67, juin 2007. Mais detalhes em GOLDSCHMIDT, Jr., A. A Brief History of Egypt. New York: Facts On File, 2008 e em JANKOWSKI, J. Egypt: A Short History. Oxford: Oneworld, 2000. 
antes de tudo, estabilidade. Assim, não foi difícil para os novos invasores se livrarem dos romanos do Oriente. ${ }^{5}$

A conquista árabe do Egito teve um impacto profundo sobre a geografia econômica e política do Mediterrâneo Oriental. Desde a Antiguidade, camponeses cultivavam um vasto leque de vegetais no vale e no delta do rio Nilo. Havia algumas espécies de trigo, centeio, cebola, alho, lentilha, feijão, numerosas verduras, uva, damasco, maçã, figo, tâmara, pêssego e melão, entre outros. Esse era o principal celeiro de Bizâncio, como o fora de Roma nos primeiros séculos da Era Cristã. Por sua vez, o porto de Alexandria fornecia têxteis e bens luxuosos vindos do Oriente para o sul da Europa. ${ }^{6}$ Agora, essa região se tornara um abastecedouro do Hijaz (parte oeste da Península Arábica) e do Levante. Como disse Eamon Gearon,

o Egito foi um prêmio de grande valor, a despeito de sua devastação nos anos recentes, dos 11 anos de governo persa, irrupções de pragas e um tempo infeliz sob os estrangeiros bizantinos. Objeto de inveja e meta de muitos construtores de impérios antigos, o Egito permaneceu uma fonte vital de grãos, especialmente para a Europa. A terra dos faraós era também conhecida como uma terra de sabedoria, lenda e mistério. Ao verem pela primeira vez as pirâmides, os invasores árabes acreditaram que tinham encontrado os silos de José. ${ }^{7}$

A médio prazo, pois tudo dependeu do ritmo de sua recuperação econômica, a incorporação do Egito ampliou enormemente os recursos financeiros do califado, assegurou-lhe uma posição estratégica no cenário militar do Mediterrâneo e fincou uma cabeça de ponte para a continuidade da expansão islâmica sobre o Norte da África. Esses foram fatores de suma

5 Cf. GOLDSCHMIDT, Jr., A. A Concise History of the Middle East. Boulder: Westview, 1999, p. 44-48; SOWELL, K. The Arab World: An Illustrated History. New York: Hippocrene, 2004. p. 33-38.

6 IKRAM, S. Egypt, Ancient: Agriculture. In: SHILLINGTON, K. (Ed.). Encyclopedia of African History. New York: Fitzroy Dearborn, 2005, v. 1, p. 415-416. Para um quadro macrorregional, ver JEHEL, G. La Méditerrannée Médiévale, de 350 a 1450. Paris: Armand Colin, 1992 e NORWICH, J. J. The Middle Sea: A History of the Mediterranean. London: Vintage, 2008.

7 GEARON, E. Arab invasions: the first Islamic empire. History Today, v. 61, n. 6, p. 46, June 2011 . 
importância. As conquistas da Síria e do Egito formaram um processo unificado, fundamental para neutralizar uma possível contraofensiva bizantina. ${ }^{8}$

A transformação do Egito em província do califado implicou a reformulação de alguns aspectos da organização espacial do poder político. Decidiu-se que era preciso construir uma nova capital. Nela ficariam o grosso das tropas estacionadas no país e a sede administrativa da província. Um centro voltado para o Hijaz e não para o Mediterrâneo, com uma estrutura urbana e uma arquitetura religiosa que expressasse a presença do Islã. Assim, Fustat, um acampamento militar localizado próximo ao rio Nilo, a cerca de 170 quilômetros da costa do Mediterrâneo, tornou-se o sítio da nova capital, em 642-643. Distante de Alexandria, centro cosmopolita muito identificado com a herança greco-romana e com a força do cristianismo dos coptas, Fustat foi moldada em função dos interesses da elite muçulmana que a partir dali governava o país. Dela era mais fácil chegar ao Mar Vermelho, caminho marítimo para Meca e Medina. E dela também era possível vigiar mais eficientemente as tribos nômades que percorriam as rotas do Saara e perceber mais prontamente quem estivesse a descer o Nilo. ${ }^{9}$ A cidade não tardou a experimentar um crescimento formidável, que se acentuou nos séculos seguintes. De acordo com Bruce Stanley,

no século IX, Fustat desenvolveu um papel econômico para complementar suas funções de segurança e de administração. A cidade tornou-se o principal porto interno do país, bem como um centro vital de produção industrial. A cidade cresceu exponencialmente, tornando-se uma das maiores cidades de Dar al-Islam. Suas elites frequentemente possuíam residências em Fustat, em Alexandria e na Arábia, comutando-as entre si. O governo de Damasco e, em seguida, de Bagdá, significou a adição de subúrbios reais, tais como al-Askar e Helwan; a construção monumental por governadores locais [...] e novas redes de comércio. ${ }^{10}$

8 BROWNE, D. Egypt: Arab conquest (639-645). In: SHILLINGTON, K. (Ed.). Op. cit., v. 1, p. 427-428; SAUNDERS, J. J. A History of Medieval Islam. London/New York: Routledge, 1996. p. $52-57$.

9 SÉNAC, P. Le Monde Musulman, des Origines au XIe Siècle. Paris: Sedes, 1999. p. 164165.

10 STANLEY, B. Cairo. In: DUMPER, R. T.; STANLEY, B. E. (Eds.). Cities of the Middle East and North Africa. Santa Barbara: ABC-CLIO, 2007. p. 108. 
Há razoável consenso entre os historiadores quanto aos primeiros governos árabes do Egito, principalmente o do general conquistador Amr ibn al-As, que dirigiu a província em duas ocasiões, entre 641 e 664. Sob seu comando, a economia agrícola foi incentivada, o êxodo rural contido, várias estradas restauradas, obras hidráulicas realizadas e a ordem tributária reorganizada. Como se sabe, em termos doutrinários ideais, os povos do Livro, os judeus e os cristãos, são considerados dhimmi, ou seja, protegidos do Islã. Eles podem manter sua fé e seus cultos, no entanto, devem abster-se do proselitismo e da exibição ostensiva de seus símbolos, aceitar um status político inferior e pagar uma taxa específica, djizya. ${ }^{11}$ É bem provável que, nos primeiros tempos da conquista, essa condição ideal fosse efetivamente real. Por um lado, os islâmicos eram minoria e precisavam contar com o concurso dos antigos funcionários governamentais de baixo escalão, em sua maioria, coptas. Compreende-se, assim, a demora no processo de arabização da papelada estatal, que passou a ser escrita apenas em árabe somente na primeira década do século VIII. Convinha, então, evitar confrontos desgastantes. Por outro lado, para que existisse um fluxo crescente de tributos era interessante que não ocorresse imediatamente uma conversão em massa ao Islã. Porém, tal situação mudou bastante no decorrer dos séculos VIII e IX.

\section{A província do Egito entre os omíadas e os abássidas, 664-868}

Excetuando-se alguns governos isolados, o quadro que os cronistas medievais pintaram do Egito posterior à administração de Amr ibn al-As é desalentador. Até 868, quando o militar de origem turca Ahmad Ibn Tulun assumiu o poder, sucederam-se dezenas de governadores que, de um modo geral, praticaram gestões extremamente repressivas e cobraram tributos cada vez mais elevados, que eram carreados, na época omíada (661-750), para Damasco e, depois, na época abássida (750-868; 905-935), para Bagdá. Raramente alguma delas caiu nas graças da memória coletiva. Expressões

11 ThORAVAL, Y. Dictionnaire de la Civilisation Musulmane. Paris: Larousse, 2001. p. 118-119; SOURDEL, D.; SOURDEL-THOMINE, J. Vocabulaire de l'Islam. Paris: P.U.F., 2002. p. 30-31. 
daquela conjuntura longa foram as numerosas revoltas populares. As primeiras rebeliões de grande monta dos coptas se deram na última década do século VII e inauguraram um ciclo que durou até a década de 830. Segundo Gawdat Gabra, um arqueólogo e historiador egípcio que foi diretor do Museu Copta do Cairo,

as revoltas mais significativas foram aquelas dos Bachmuritas, que estavam estabelecidos nas terras pantanosas do Delta e viviam de vender papiro, da caça de aves e da pesca. Deste modo, eles não eram dependentes do sistema central de irrigação controlado pelo governo. Ademais, sua região pantanosa, com suas moitas e juncos, não era de fácil acesso para os exércitos organizados. $^{12}$

Um fator agravante de todo esse estado foi a decisão tomada pelo califado omíada, na primeira metade do século VIII, de conceder a comandantes militares uma iqta - o direito (não hereditário) de auferir renda sobre uma parcela de terra, que pode ser rural, urbana ou ambas - como pagamento pelos serviços prestados. A renda dos detentores dependia, por suposto, do que fosse produzido ou comerciado na área concedida. ${ }^{13}$ Daí o inevitável aumento da violência contra as camadas populares, formadas por egípcios nativos e por um número crescente de árabes. Violência que já não era exercida apenas pelas autoridades, mas também por tropas pessoais dos militares agraciados pelo califa. Outro fator agravante das tensões foi a migração estimulada pelo Estado de tribos da Arábia para o vale do Nilo, em particular a dos Qays, provenientes do Iemen. ${ }^{14}$ Ela começou durante o governo do califa Hisham (724-743) e se expandiu pelos séculos VIII e IX. Não tardou a ocorrer competição pelas terras férteis entre velhos e novos egípcios. E não demorou para que ela ganhasse cores de confronto religioso. Não surpreende que, em 829-832, os Bachmuritas tenham novamente erguido as armas. ${ }^{15}$

12 GABRA, G. The A to Z of the Coptic Church. Lanham, Toronto, Plymouth: Scarecrow, 2009. p. 74.

13 Cf. SATO, T. Land tenure and ownership, or iqta'. In: MERI, J. (Ed.). Medieval Islamic Civilization: An Encyclopedia. v. 2. New York/London: Routledge, 2006. p. 447-449.

14 SOURDEL, D. Histoire des Arabes. Paris: P.U.F., 1976, cap. I; ROBIN, C. J. Les tribus de l'Arabie déserte. L'Histoire, v. 272, p. 34-37, janvier 2003.

15 GABRA, G. Op. cit., p. 74. 
Gawdat Gabra sustentou que foi essa sanguinolenta revolta o motivo da ida do califa Al-Mamun ao Egito, em 832. O dirigente islâmico levou consigo Dionisio de Tell Mahre, o patriarca de Antióquia, para que este e Yusab, o patriarca copta de Alexandria, convencessem os rebeldes a deporem as armas e se deslocarem para outra região, gozando de um perdão geral. Diante da recusa dos Bachmuritas, desencadeou-se feroz repressão. Igrejas e residências foram destruídas e os revoltosos que sobreviveram foram vendidos, junto com seus familiares, no mercado de escravos de Damasco. ${ }^{16}$ Essa foi a última grande rebelião dos coptas. Nas décadas seguintes, tanto como efeito de um forte sentimento de resignação diante da presença dos ocupantes árabes quanto por causa da ação determinada do Estado califal, aumentaram exponencialmente as conversões ao Islã. Nas palavras de James Jankowski,

o ciclo de revolta e repressão através do século oito e do começo do século nove operou em duas direções. Por um lado, taxas elevadas e sublevações civis permanentes minaram a estabilidade econômica do país, produzindo desagregação comercial, fuga de camponeses e o consequente declínio do produto agrícola e das rendas dos impostos. Por outro lado, a supressão brutal das revoltas pelas forças do governo central teve como efeito o demonstrar a permanência da nova ordem. Assim, isso deve ter contribuído para a gradual adoção tanto do árabe quanto do Islã pelos egípcios. ${ }^{17}$

A viagem de Al-Mamun também provocou forte impacto sobre os árabes. Até então, mesmo os mais pobres achavam-se a ocupar um status superior ao dos nativos. Eles tinham a religião da elite dirigente, o Islã, e falavam o idioma pelo qual o arcanjo Gabriel comunicou a mensagem divina ao profeta Muhammad. Uma língua, enfim, sagrada. Agora, porém, a própria língua falada na corte de Bagdá estava a ganhar novos sotaques e adições. Começava, ainda sutilmente, mas de maneira que já se podia ver, um novo tempo. O califa não levou consigo apenas o patriarca de Antióquia e seu cortejo, mas um séquito de militares de origem turca que

16 GABRA, G. Op. cit., p. 75.

17 JANKOWSKI, J. Egypt: A Short History. Oxford: Oneworld, 2000. p. 35. 
compunham sua guarda pessoal de soldados-escravos. Sua intenção não era apenas estabelecer a paz no Egito, mas promover reformas que isolassem os focos de insubordinação no interior da elite dirigente regional. Al-Mamun esperava que, com o aporte dos militares turcos, a administração da província pudesse se tornar mais eficiente, uma vez que, por razões étnicas e pela fidelidade que devotavam à pessoa do califa, eles não deviam muitas satisfações aos notáveis árabes locais, a base de apoio dos governadores tão detestados pelo povo. ${ }^{18}$

\section{Tensões nas elites dirigentes e pressões centrífugas no Estado Abássida}

Esse corpo de soldados turcos, que estava prestes a realizar grandes façanhas, foi criado para proteger a pessoa do califa e para evitar a reprodução, no seio das forças armadas e das burocracias provinciais, de vetores centrífugos capitaneados por setores tradicionais da elite árabe. Ele era composto, inicialmente, por guerreiros islamizados cujos chefes se puseram a serviço do governante. Logo passou a ser formado basicamente por indivíduos obtidos por meio de captura, tributo ou compra em regiões distantes da sede do Império Abássida, mormente na Ásia Central. Tais soldados-escravos eram chamados de mamelucos (mamluk = possuído por alguém). ${ }^{19}$ A guarda turca não demorou a se transformar no mais forte e ameaçador dos vetores que desestabilizavam a autoridade califal. Durante os três governos que, intermediados por anos de crises políticas e tronos constantemente vagos, sucederam ao de Al-Mamun, o de Al-Mutasim (r: 833-842), o de Mutawakil (r: 847-861) e o de Mutamid (r: 869-892), aqueles militares passaram a ocupar cargos de governadores em diversas províncias e viram a ascensão ao poder político de facto de seus comandantes. Ademais, a concentração das tropas turcas em Bagdá causou grandes

18 Cf. GOLDSCHMIDT, Jr., A. A Concise History of the Middle East, 1999. p. 69-71, 78-79.

19 BOSWORTH, C. E. The historical background of Islamic Civilization. In: SAVORY, R. (Ed.). Introduction to Islamic Civilization. New York: Cambridge University Press, 1994. p. 20-22; WATERSON, J. The Mamluks. History Today, v. 56, n. 3, p. 21-27, March 2006. 
problemas. Os soldados eram dados a arruaças e praticavam atos gratuitos de violência contra a população. Por isso, em 836, Al-Mutasim transferiu seus quartéis e a própria corte califal para Samarra, uma cidade à beira do Rio Tigre, cerca de 120 quilômetros ao norte de Bagdá, que só voltaria a ser capital na década de $890 .{ }^{20}$ Neste sentido, observada a distância, a decisão de compor essas tropas foi um tiro no pé. Na época, porém, foi vista como necessária, seja pela consideração profunda que os árabes e persas tinham pelas virtudes guerreiras dos turcos, seja pelo estado de instabilidade crônica e de permanente ameaça de fragmentação criado pelas disputas entre segmentos da elite do califado. ${ }^{21}$

Ao longo do século IX, o Estado Califal foi abalado por uma série de sublevações e sofreu o assalto de diversas iniciativas descentralizadoras ou mesmo de cunho autonomista. A mais impressionante foi, certamente, a dos escravos africanos do sul da Mesopotâmia, conhecida como Revolta dos Zanj (869-883). Empregados em grande quantidade nas obras de secagem de pântanos nas áreas próximas ao Golfo Pérsico, os rebeldes, quase todos adquiridos de negociantes que os levavam da África Oriental, conseguiram estabelecer alianças com famílias camponesas da região e edificaram um pequeno Estado governado por uma camada dirigente que se inspirava na própria corte califal. As tropas da aristocracia fundiária local foram rechaçadas e os grandes proprietários tiveram que fugir. A cidade portuária de Basra foi praticamente destruída, em 871, e colunas rebeldes chegaram a atacar Bagdá, em 878. Por duas décadas a área conflagrada conseguiu manter sua independência, o que obrigou o califado a mobilizar vastos recursos militares para debelá-la, quase que enxugando os cofres do tesouro. ${ }^{22} \mathrm{Na}$ mesma época, grupos sectários, como os Caradjitas, os Carmatas, os Zaiditas e os Ismaelitas, também se insurgiram por todos os rincões. Alguns desses movimentos assumiam traços messiânicos, mas é importante notar que eles

20 Ver WHITAKER, J. L. Samarra. In: DUMPER, R. T.; STANLEY, B. E. (Eds.). Op. cit., p. 323-327.

21 Cf. GORDON, M. The Rise of Islam. Indianapolis: Hackett, 2008, p. 63-ss; KENNEDY, H. Mongols, Huns and Vikings: Nomads at War. London: Cassel, 2002.

22 Ver AFOLAYAN, F. Zanj slave revolts (c. 869-883). In: RODRIGUEZ, J. P. (Ed.). The Historical Encyclopedia of World Slavery. v. II. Santa Barbara: ABC-CLIO, 1997. p. 713 e FISHER, A. Zanj. In: FINKELMAN, P.; MILLER, J. C. (Eds.). Macmillan Encyclopedia of World Slavery. v. II. New York/ London: Simon \& Schuster Macmillan/Prentice Hall International, 1997. p. 967-968. Tb. ADEKUNLE, J. O. East African States. In: FALOLA, T. (Ed.). Africa. v. I. Durham, NC: Carolina Academic Press, 2000. p. 191-206. 
não expressavam apenas discordâncias doutrinárias e políticas no interior do Islã, mas também as insatisfações dos camponeses e de determinados setores urbanos, como os pequenos mercadores e artesãos, profundamente explorados por uma elite dirigente que tendia a se comportar como casta $\mathrm{e}$ se aboletava em residências suntuosas nas grandes cidades. ${ }^{23}$

O Império dos Abássidas estava organizado administrativamente em províncias dirigidas por um governador (wali) nomeado pelo califa. Por meados do século IX, as principais províncias eram o Magreb (norte da África), o Egito, o Iraque, a Síria-Palestina, o Khurasan (norte-nordeste do Irã) e a Arábia. O mandatário provincial era assistido por altos burocratas que cuidavam das finanças, das tropas, do policiamento e da justiça. Líderes das comunidades de protegidos (dhimmi) também participavam do processo administrativo. Ademais do serviço religioso entre judeus e cristãos, eles coletavam os impostos, decidiam a alocação de recursos em termos locais, ministravam a justiça no seio da sua comunidade e atuavam como canais de ligação com os representantes do califa. No século VIII e no começo do século IX, os mandatos dos governadores foram, de um modo geral, bem curtos. Em alguns casos porque eles eram homens velhos que não tardaram a falecer; noutros, porque preferiram voltar à corte; noutros porque foram substituídos por sua incompetência no trato com as massas revoltas. Essas causas, porém, foram secundárias. A maior parte dos mandatos foi encurtada por intrigas palacianas, por denúncias de abusos de autoridade feitos por subalternos, por tentativas de enriquecimento pessoal à revelia dos interesses do califado e por disputas malsucedidas com setores da classe dominante local. ${ }^{24}$

Al-Mutawwakil (r: 847-861) tentou reduzir esses problemas nomeando seus próprios filhos como administradores provinciais assessorados por militares turcos. Assim, Al-Muntasir ficou responsável pelo Egito e pelo norte da Mesopotâmia (Gezira), Al-Mutazz pelo Khorasan e Al-Muayyad pela Síria-Palestina. O primeiro acabou por assassinar o pai por meio de um de seus guardas turcos. Tal gesto inaugurou anos de profunda crise política no Império (de 861 a 870), cuja cabeça ficou dilacerada pelas disputas pelo trono entre os filhos do califa morto, que não passavam, em grande

23 Cf. WATT, W. M. A Short History of Islam. Oxford: Oneworld, 1996. p. 101-112; SOURDEL, D. L'Islam. Paris: P. U. F., 1984, cap. IV.

24 Cf. SÉNAC, P. Op. cit., p. 66-68. 
medida, de títeres dos chefes militares. ${ }^{25}$ Para melhor compreender tudo isso, é preciso notar que

o princípio de uma monarquia hereditária, transmitido do pai ao filho mais velho, nem sempre se impunha. Os califas escolhiam seus sucessores no seio de sua família, mas de acordo com combinações diferentes, complicadas, ainda, pela poligamia: seja um filho a suceder seu pai, seja um tio, um irmão ou um primo. Para evitar as alianças matrimoniais que poderiam trazer novos pretendentes para a comitiva do soberano, os califas tomavam por mulher as concubinas escravas, de tal maneira que todos os califas a partir dos filhos de Al-Rashid foram filhos de escravas. ${ }^{26}$

Com o tempo, esse estado crônico de instabilidade na corte califal levou a um afrouxamento das relações entre a capital e as províncias e foi percebido por alguns governadores e oficiais militares como um caldo de oportunidades para a acumulação de poder e prestígio. Não há espaço nestas páginas para se mencionar todas as iniciativas então desencadeadas de criação de principados ou emirados mais ou menos autônomos. Interessa de agora em diante somente o que aconteceu no Egito e suas repercussões na Síria-Palestina, uma área de tensão permanente entre o Estado Abássida e Bizâncio.

\section{O emirado de Ibn Tulun no Egito e na Síria, 869-884}

Em 868, Al-Mutazz (r: 866-869) conferiu a Bakbak (ou Bayakbak, ou Baqbaq), um general de origem turca que comandava uma de suas tropas, o governo do Egito. O militar, porém, preferiu ficar no Iraque e enviou seu enteado, Ahmad Ibn Tulun (835-884), filho de um escravo originário de Bukara, em seu lugar. Tomando por base o que disse Abu ibn Taghri Birdi

25 GOLDSCHMIDT, Jr., A. A Concise History of the Middle East, p. 70-77; SOWELL, K. The Arab World: An Illustrated History, p. 58-59.

26 SÉNAC, P. Op. cit., p. 65. 
(c. 1410-1470), em sua crônica histórica do Egito desde a conquista árabe, um escritor recente, Ahmad Shalaby, afirmou que, além de ter se destacado como soldado durante seu treinamento no quartel dos turcos em Samarra (no Iraque), Ibn Tulun era poliglota, recebeu lições de jurisprudência e foi fortemente influenciado pela escola hanafita, chegando a frequentar os imãs de Tarsus (no sul da Turquia). ${ }^{27}$ Essa formação deu-lhe grande notoriedade. Em 854, ele foi designado para um cargo administrativo em Damasco. Entre as suas incumbências estava cuidar dos postos de coleta e vigilância nas fronteiras da província síria. Dois anos depois, ele foi para Wasit (no Iraque), nomeado para a guarda que devia vigiar Al-Mustasin, o califa deposto por Al-Mutazz. Suas atitudes na ocasião, entre elas a recusa de se envolver numa trama para assassinar o ex-califa, lhe teriam granjeado mais respeito ainda, o que se traduziu em ampliação das suas chances de maior ascensão social e política nos quadros da elite do califado. Assim, quando foi para o Egito, ele possuía experiência como administrador e conhecimentos muito úteis da geografia humana do Levante, fatores que, no futuro, certamente foram decisivos para delinear suas decisões políticas e militares. ${ }^{28}$

Ao chegar em Fustat, o preposto do governador demitiu o controlador dos impostos (amil) Ibn al-Mudabir (ou Muddabir, ou Mudabbir), tido por infame, e assumiu o cargo, tornando-se responsável pelo envio dos tributos para Bagdá. Ibn al-Mudabir, contudo, alegando ter sido nomeado pelo califa, resistiu. Foram quatro anos de disputas que extrapolaram em muito os dois indivíduos e dividiram em claques distintas a elite provincial. Por fim, o antigo coletor foi transferido para a Síria. ${ }^{29}$ Nesse ínterim, Ahmad realizou manobras pessoais muito bem-sucedidas. Seu padrasto, o wali titular do Egito, foi assassinado em 869 (para alguns, em 870). O novo governador, Yarjukh, que era seu sogro e não viveu por muito tempo, fez dele uma espécie de governador auxiliar e o manteve na função de coletor dos impostos. Há, porém, certas dificuldades para se estabelecer a cronologia neste ponto. A maioria dos historiadores afirma que, após a morte

27 Sobre a escola jurídica e teológica hanafita, que deriva seu nome do jurista persa Abu Hanifa (m. 767), veja-se a síntese de SOURDEL, D. L'Islam, p. 47-48.

28 SHALABY, A. Islam in Egypt, Nubia, and Sudan. In: EL HAREIR, I.; M'BAYE, R. (Eds.). The Different Aspects of Islamic Culture. v. III. Paris: Unesco, 2011. p. 224. Tb. SEARS, S. Ibn Tulun. In: MERI, J. (Ed.). Op. cit., v. 1, p. 373-374.

29 LITTLE, D. P. Egypt: from the Islamic conquest to 1250. New Encyclopaedia Britannica, $15^{\text {th }}$ edition, 1993, Macropaedia, v. 18, p. 131. 
de Yarjukh, Bagdá nomeou Ibn Tulun governador. Mas há os que dizem que ele exerceu o interinato até que, em 872, o califa nomeou seu filho, Jafar, que era menor de idade, para o governo do Egito e das províncias ocidentais. ${ }^{30} \mathrm{Na}$ prática, todos concordam, era Ibn Tulun quem mandava. É também elevado o consenso a respeito do prestígio que ele tinha junto à população egípcia. Ahmad Shalaby observa que ele era "renomado por sua força e suas tendências reformistas", ademais de ser beneficiado pela péssima consideração que o povo tinha por seus antecessores. ${ }^{31}$

As táticas de Ahmad eram facilitadas pelas viragens políticas na capital do Império. Al-Mutazz faleceu em 869. Seu sucessor, Al-Muhtadi, governou menos de um ano e foi seguido por Al-Mutamid, jovem demais para a titularidade do trono, portanto, submetido ao controle de um regente, seu irmão Al-Muwaffaq, que tinha evidente interesse em assumir plenamente o poder. ${ }^{32}$ Um ambicioso governador provincial não tardaria a perceber as possibilidades centrífugas contidas nesse quadro político. Sua conduta diante da autoridade bagdadense era claramente estudada. Ele procurava agradar o califa com mimos, presenteando-o com raridades egípcias e nunca deixando de mencionar o nome do comandante dos crentes nas orações feitas em público. Ao mesmo tempo, agia para aprofundar sua autonomia como governante. A mais impactante das ações foi sua decisão de não mais enviar para Bagdá todo o montante dos impostos arrecadados. Em 876, ele recolheu 4,3 milhões de dinares, mas só enviou 1,2 ao regente do califado, deixando 2,2 à disposição de Al-Mutamid e mantendo o restante no próprio Egito. ${ }^{33}$ No parecer de Claudio Lo Jacono, ele pretendia explorar e reforçar o dissenso no seio da família dirigente. Tanto que sugeriu que podia hospedar e proteger o califa se este desejasse lutar pelo poder contra seu irmão. A trama, que seria levada a cabo em 882, foi descoberta e o califa foi trancado em sua residência em Samarra. Para Arthur Goldschmidt, os objetivos de Ibn Tulun não paravam no apoio ao jovem califa. Embora ele não aduza nenhuma fonte para comprovar essa ideia, sua tese é a de que o sonho de Ahmad era transferir o próprio califado do Iraque para o Egito. ${ }^{34}$

30 SEARS, S. Op. cit., p. 373.

31 SHALABY, A. Op. cit., p. 245.

32 SÉNAC, P. Op. cit., p. 65.

33 LO JACONO, C. L'Egitto dalla conquista araba a Napoleone. In: BRANCA, P. (a cura di). Egitto: Dalla Civiltà dei Faraoni al Mondo Globale. Milano: Jaca Books, 2007. p. 69.

34 LO JACONO, C. Idem; GOLDSCHMIDT, Jr., A. A Brief History of Egypt, p. 43. 
Seja como for, à diferença dos cleptocratas que infestaram o Egito nos séculos anteriores, ele procurou investir uma boa parte dos tributos arrecadados em diversos tipos de melhoramentos, como a construção de palácios, de um hospital para homens e mulheres (erguido entre 872 e 874), de um hipódromo e de um bairro inteiro em Fustat; a ampliação da malha de mesquitas (inclusive edificando a muito suntuosa que leva seu nome e ainda hoje recebe crentes do Islã de todo o mundo); a realização de obras de irrigação nas margens do Nilo, reativando a rede de canais e de cisternas, que resultaram em desenvolvimento agrícola e consequente ampliação dos impostos captados. $\mathrm{O}$ fomento ao crescimento da produção e o controle dos preços permitiu notável melhoria da vida em todos os setores da população. Outra ação que lhe trouxe fortes dividendos em termos de prestígio foi seu ataque à burocracia prepotente e corrompida por meio de uma reforma fiscal. Para obter apoio nas tropas e na administração pública, Ibn Tulun fez largo uso da distribuição de iqta. Todavia, o emirado era caro de manter e somente seu exército absorvia 1 milhão de dinares. ${ }^{35}$ Uma boa parte de todo esse custo elevado decorria do permanente confronto com grupos nômades que atacavam as cidades a partir do deserto. Mas também tinha a ver com as intenções expansionistas do próprio Ahmad, em particular no Levante.

A Síria, escreveu Philip Hitti, foi uma "terra de rebeldes contra o governo abássida". Segundo esse grande e orgulhoso historiador árabe-americano da primeira metade do século XX, os cristãos e os judeus daquela região se levantaram contra várias medidas discriminatórias adotadas a partir do califado de Al-Mamun. Entre elas, a obrigação de usar trajes amarelos para realçar sua pertença religiosa, a proibição de montar cavalos (só poderiam montar asnos e mulas com selas de madeira com adornos e cores específicas), a obrigação de manter os túmulos ao rés do chão e o dever de afixar em suas casas imagens de madeira representando seres demoníacos. ${ }^{36}$ Tal clima rebelde, que também envolvia setores urbanos populares muçulmanos, atravessou décadas e constituiu o pano de fundo das iniciativas do wali da Síria-Palestina, Ali ibn Amajur, por ampliação de sua autonomia frente a Samarra na década de 870. Esse ambiente de forte insatisfação no seio de uma população que ainda era formada por um grande número

35 LO JACONO, C. Ibidem, p. 69-70; SEARS, Op. cit.; SUNDELIN, L. Egypt: Tulunids and Ikhshidids, 850-969. In: SHILLINGTON, K. (Ed.). Op. cit., v. 1, p. 430-431.

36 HITTI, P. K. Syria: A Short History. New York: Macmillan, 1959. p. 154. 
de judeus e cristãos é um dado que muitos autores deixam de mencionar quando comentam as razões que levaram Ibn Tulun a intervir naquela região. Autorizado pelo tenente dos crentes, a quem, pelo que sugerem as fontes, ele próprio se oferecera, o mandatário do Egito reuniu uma tropa de 24 mil turcos e 42 mil sudaneses e, em 877, partiu em direção à Síria. Foi um avanço rápido de Al-Ramlah, no sul, até Damasco, Homs, Hamah e Alepo. Não havia oponentes de peso. Apenas Antióquia esboçou uma reação, mas foi logo submetida. Ele também cuidou de mobilizar uma frota que organizara nos anos anteriores com o pretexto de preparar a defesa contra os bizantinos. Ela agora servia para patrulhar e ameaçar a costa levantina. ${ }^{37}$

No final de 879, Ahmad era o wali efetivo da Síria e, segundo Philippe Sénac, "proclamou-se independente e exigiu do califa o direito de dispor livremente das rendas das províncias sobre as quais havia imposto sua autoridade" ${ }^{38}$ A ampliação de sua base tributária permitiu que ele acumulasse um poder militar que rivalizava com o da capital abássida. Qatai (al-Qata'i, ou Katai), a cidade que ele edificara ao lado de Fustat, expressava essa rivalidade. Tal como em Samarra, onde ele fora educado, lá havia um complexo palaciano, que incluía a famosa mesquita e o quartel que abrigava as tropas de escravos e mercenários vindos do Egito, do Mediterrâneo, do Sudão e das tribos turcas procedentes da Ásia Central. De acordo com Ahmad Shalaby,

ele selecionou os camareiros, os secretários, os assistentes e a escolta montada, e organizou a força policial de modo a apoiar-se nela para garantir a paz e manter a segurança. Ele organizou, do mesmo modo, o judiciário e o gabinete do muhtasib, ou inspetor do mercado, e nomeou pessoalmente os juízes, uma vez que isso era um importante símbolo de independência. Um dos juízes mais famosos foi Bakkar ibn Qutayba, que se recusou a amaldiçoar Al-Muwaffaq no púlpito quando Ibn Tulun assim ordenou; disso resultou que Ibn Tulun mandou-o para a prisão. ${ }^{39}$

Muito significativamente, o emir passou a cunhar moeda contendo seu nome, além do nome do califa, o que provavelmente denotava menos o temor de exercer a autonomia plena do emirado do que o receio

37 SHALABY, A. Op. cit., p. 245; SUNDELIN, L. Op. cit., p. 131.

38 SÉNAC, P. Op. cit., p. 112.

39 SHALABY, A. Op. cit., p. 247. 
de desagradar a parcela da população muçulmana que, aparentemente, lhe apoiava. Seus domínios logo foram estendidos até os limites com a Líbia e suas tropas fustigaram várias vezes os bizantinos na Ásia Menor. Donald Little resumiu os fatos da seguinte maneira:

Pela primeira vez desde os faraós, o Egito tornou-se virtualmente autônomo e o montante de suas rendas permaneceu dentro de suas fronteiras. Ainda mais, o Egito tornou-se o centro de um pequeno império quando Ibn Tulun conquistou a Síria, em 878-879. ${ }^{40}$

Naquele momento, cabe lembrar, a capacidade do Estado abássida de recuperar o Egito e o Levante era praticamente nula. Como já se disse, os cofres do tesouro estavam exauridos pelo confronto com os Zanj, no sul do Iraque. Fator agravado pela ausência das remessas de Fustat. Não havia como reequipar as tropas do califa e partir imediatamente para novas guerras ${ }^{41}$ Tudo isso permitiu que Ibn Tulun pudesse fortalecer seu governo. Ele aumentou permanentemente a frota construindo navios em um estaleiro localizado na ilha fortificada de ar-Rawda e continuou recrutando mercenários e comprando escravos para suas tropas. Quando ele morreu, em 884, sua autoridade política estava firmemente estabelecida entre a Líbia e o norte da Síria. Seu emirado fora bafejado pela sorte de não precisar enfrentar fatores adversos de forte impacto. Pelo pouco que se sabe, o Nilo ajudou, mantendo-se no ciclo regular de anomalias (cheias arrasadoras ou águas que não sobem o suficiente) a cada 10 anos grosso modo. Também não ocorreram pestes devastadoras, como as que assolaram o Mediterrâneo Oriental entre os séculos VI e VIII, ou as que estavam por vir no final do século $\mathrm{X} .{ }^{42} \mathrm{Os}$ bandos nômades já islamizados que atacavam com frequência as aldeias e pequenas cidades - em particular as de maioria copta - foram relativamente detidos e até foi possível desviar algumas rotas tradicionais dos guerreiros

40 LITTLE, D. P. Op. cit., p. 131

41 SEARS, S. Op. cit., p. 834.

42 Para o ciclo das águas do grande rio, ver SARTRE, M. La crue du Nil: religion et géographie. L'Histoire, v. 211, p. 48-54, juin 1997 e COLLINS, R. O. Nile River. In: MIDDLETON, J.; MILLER, J. P. (Eds.). New Encyclopedia of Africa. v. 4. Detroit/London: Charles Scribner's Sons/Thomson Gale, 2008. p. 58-61. Sobre as epidemias, STATHAKOPOULOS, D. Plague of Justinian; First Pandemic. In: BYRNE, J. P. (Ed.). Encyclopedia of Pestilence, Pandemics, and Plagues. v. 2. Westport, Conn./London: Greenwood, 2008. p. 532-535. 
do deserto para alvos núbios no Alto Nilo. ${ }^{43}$ Ademais, embora ele não tenha rompido explicitamente com Bagdá e mantivesse o nome do califa nas moedas impressas no emirado, foi obrigado a rechaçar uma tentativa militar do regente Al-Muwaffaq de recuperar o controle do Egito e da Síria. Pelo que disseram os cronistas, ambos se xingavam e se amaldiçoavam mutuamente, um em Samarra, outro em Fustat, nas orações de sexta-feira. ${ }^{44}$

Durante o governo de Ibn Tulun, o Egito continuou exportando suas mercadorias tradicionais para diversas regiões dentro e fora do mundo islâmico. Por ele também passavam os peregrinos africanos que se dirigiam às cidades santas e mercadores do Magreb que iam para o Iraque, a Arábia ou o Levante. No meio do século IX, al-Jahiz, um letrado que fez muito sucesso na corte de Bagdá, registrou que, entre as mercadorias que lá chegavam provenientes do Egito, estavam burros de carga, tecidos de seda fina, papiro, bálsamo e topázio de boa qualidade. Já da África do Norte chegavam animais, como as panteras e os falcões negros, feltro e matérias-primas para as fábricas de tecidos e para os curtumes. ${ }^{45}$ Ao decidir marcar a autonomia de seu emirado com a construção de uma nova capital, Ahmad, que dispunha dos tributos não remetidos a Samarra, gerou empregos na construção civil e ampliou o mercado de bens artesanais, agrícolas e pecuários. A produção de papiro e de tecidos se expandiu. Assim como o tráfico de escravos provenientes da Europa, da Ásia e da África Negra. ${ }^{46}$ $\mathrm{O}$ emir teve, ainda, habilidade para se cercar de notáveis locais que lhe assessoravam em questões comerciais. ${ }^{47}$

\section{Ocaso e fim do emirado dos Tulúnidas, 884 a 905}

Philip Hitti afirmou que Ibn Tulun foi "um típico ditador militar" [que] "construiu uma poderosa máquina militar da qual dependia para

$10-12$.

43 COLlinS, R. O. Africa: A Short History. Princeton: Markus Wiener, 2006. p. 49.

44 LITTLE, D. P. Op. cit., p. 131; SHALABY. Op. cit., p. 245.

45 Apud SAUVAGET, J. Historiens Arabes: Pages Choisies. Paris: Maisonneuve, 1946. p.

46 GOLDSCHMIDT, Jr., A. A Brief History of Egypt, p. 54; HITTI, P. K. The Near East in History. Princeton: Van Nostrand, 1961. p. 277-279.

47 LO JACONO, C. Op. cit., p. 69-70. 
manter-se no trono". E aduziu que, "como para justificar sua usurpação do poder aos olhos dos súditos, ele lançou um programa de obras públicas, que não tiveram paralelo desde os dias dos Faraós". ${ }^{48}$ Todavia, ele se esqueceu de três outros fatores fundamentais. O primeiro foi a reprodução no Egito e, depois, na Síria, na Mesopotâmia e na Líbia de um mecanismo bem-sucedido de cooptação e costura de lealdades pragmáticas adotado pelos califas abássidas, qual seja, a distribuição de iqta para os militares que lhe apoiavam e obtinham sucessos nas conquistas. ${ }^{49} \mathrm{O}$ segundo foi o fato de que, em comparação com o que havia antes, a burocracia era eficiente. Não é possível ter uma ideia precisa das reações das camadas populares ao regime do primeiro tulúnida. Mas, aparentemente, considerando que não há notícias sobre revoltas significativas naquele período e considerando, do mesmo modo, que, após a restauração abássida, em 905, ocorreram diversos motins, Ibn Tulun contava com significativo apoio das massas ou, o que também deve ser cogitado, com súditos muito bem controlados pela força policial. Esta, por sinal, foi alimentada permanentemente pelo recrutamento de mercenários e pela compra de escravos-soldados. Ademais, foi uma época de crescimento econômico e ampliação das oportunidades de emprego. $\mathrm{O}$ terceiro fator foi a capacidade do mandatário de associar suas ações aos presumidos interesses gerais do califado. Como quando enviou tropas e navios para combater os bizantinos, dando a esses empreendimentos um certo sentido de jihad, de combate aos inimigos da Casa do Islã. Ou quando tomou a Síria e a Gezira iraquiana em nome do Tenente dos Crentes. ${ }^{50}$

O sucessor de Ahmad foi seu filho Khumarawayh (ou Khamarawayh), que tinha 20 anos de idade. Beneficiado por um novo contexto de tensões militares no califado - pois a seita ismaelita dos Carmatas se insurgira no sul do Iraque e no sudeste da Arábia (em Kufah e no Bahrain), criara um Estado próprio e muito rapidamente obtivera adeptos na Síria -, Ibn Tulun encetara negociações com Samarra para garantir o reconhecimento formal da autoridade do seu herdeiro. ${ }^{51}$ Ao assumir o controle

48 HITTI, P. K. Op. cit., p. 161.

49 LO JACONO, C. Op. cit., p. 70.

50 SEARS, S. Tulunids, p. 835. Para as campanhas contra Bizâncio, LANE-POOLE, S. Later Egypt: In the Middle Ages. In: VISCOUNT BRYCE et al. The Book of History. v. 5. New York/London: Grolier Society, 1915. p. 2144.

51 Vejam-se os comentários de ADAMEC, L. Historical Dictionary of Islam. Lanham, Toronto, Plymouth: Scarecrow, 2009. p. 311; tb. GOLDSCHMIDT, Jr., A. A Concise History of the Middle East, p. 74-75. Sobre os ismaelitas, LANDO, F. Medio Oriente: Historia, Política y Cultura. Madrid/Buenos Aires: Ciudad Argentina, 2004. p. 116-129. 
do emirado - assim expressando a formação de uma breve dinastia, os Tulúnidas -, o jovem pôde capitalizar por algum tempo a força do legado paterno, porém, não parecia ter a mesma firmeza de propósitos e a mesma capacidade de angariar apoio. As descrições que sobraram de suas ações falam de um governante perdulário, que fez uso do tesouro para erguer em Qatai um palácio decorado com árvores exóticas, um aviário e um zoológico. Também falam de bebedeiras e outras extravagâncias que não coadunavam com o que se esperava de um bom muçulmano, em particular alguém que disputava prestígio com o próprio comandante abássida dos crentes. Seja como for, exageros dos desafetos de ontem e de hoje à parte, ele foi capaz de aproveitar as tropas disciplinadas e leais de que dispunha para expandir o domínio da dinastia sobre a Cirenaica, a oeste, e uma parte da Mesopotâmia, a leste. Ademais, em 892, Khumarawayh recebeu do califa a concessão por 30 anos do Egito, da Síria, da Cilícia e do norte da Mesopotâmia (excluindo Mosul). Em troca, devia mandar 300 mil dinares anualmente para Bagdá e reconhecer a autoridade superior do califa como chefe da comunidade dos crentes. ${ }^{52}$

Uma das gastanças de que reclamaram os cronistas e quase levou o tesouro egípcio à exaustão foi precisamente parte das negociações de Khumarawayh com Bagdá. Tratou-se do dote de uma de suas filhas, Qatar Hindi, que casou com o califa Al-Mutadid. Note-se que é bem possível, como sugere Ahmad Shalaby, que esse matrimônio tenha contribuído para o adiamento da decisão califal de retomar o controle do Egito e da Síria. ${ }^{53}$ Mas o confronto era inevitável. Assim como era inevitável - dadas as ações pouco recomendáveis de quem precisava estar, como estivera seu pai, benquisto pela população - a crescente perda de apoio do mandatário tulúnida no Egito. Da Síria e das demais dependências coloniais - que foram tomadas e incorporadas à força - seria ingênuo esperar grandes aplausos. Mas era fundamental cativar o povo do delta e o vale do Nilo, que ainda guardava na memória o tempo dos abusos dos governadores abássidas. Em 895 (ou 896), ele foi assassinado. É bem provável que tenha sido vítima de alguma conspiração palaciana, mas as versões que sobraram sugerem uma causa de outra ordem: apaixonado por uma das concubinas do emir, um de seus

52 SÉNAC, P. Op. cit., p. 112. Tb. LANE-POOLE, S. Op. cit., p. 2143-2144.

53 SHALABY, A. Op. cit., p. 246. 
escravos invadiu o harém e o matou. ${ }^{54}$ Abu Asakir Jaysh, um garoto de 14 anos, foi o sucessor de Khumarawayh. No entanto, ele permaneceu apenas seis meses no cargo. As fontes parafraseadas por historiadores contemporâneos o dão como bêbado inveterado e absolutamente incapaz de lidar com as disputas entre as cortesãs. Por decisão dos juristas, ele foi encarcerado e morto pelos militares. Mas estes puseram em seu lugar alguém mais inexperiente ainda, seu irmão Abu Musa Harun, de 13 anos. Esse, no entanto, foi mantido à cabeça do emirado - mas, por suposto, não no cérebro do poder - até as vésperas da queda da dinastia, em $905 .{ }^{55}$

Em 899, Bagdá, que voltara a ser a sede do califado, decidiu rever os termos do acordo que reconhecia a titularidade tulúnida. Os domínios da dinastia foram reduzidos ao Egito e à Síria e o tributo anual a ser enviado ao califa passou para 450 mil dinares. Era um sinal de que o declínio do emirado estava começando a ficar evidente ${ }^{56}$ Al-Mutadid faleceu em 902. O novo califa, Al-Muktafil, não tinha quaisquer laços pessoais com os herdeiros de Ibn Tulun. E alimentava um projeto de reunificar o que pudesse do antigo Império Abássida. Naquele mesmo ano, tendo por meta o combate aos Carmatas da Síria, essa província foi invadida e reintegrada ao domínio califal. Em 904, uma enorme força militar - exército e marinha - foi arregimentada para retomar o Egito, sob o comando do general Muhammad ibn Sulayman. A invasão começou em finais do mesmo ano e não encontrou resistência muito acirrada. Pelo contrário, ela foi favorecida pela decisão de um dos comandantes tulúnidas, Badr, de passar para o lado dos guerreiros do califa. Enquanto as tropas califais avançavam por terra e barcos armados subiam o Nilo, em Qatai, um complô liderado por seus tios Ali e Shaiban levou à morte de Harun, o jovem emir. O segundo assumiu o trono, mas não ficou sentado por mais do que uns poucos dias. Premido pela força restauradora dos abássidas e sem tropas que lhe fossem leais, ele se rendeu, em meados de 905 . Nas semanas que se seguiram à queda dos Tulúnidas, Qatai foi praticamente destruída. Apenas a grande mesquita ficou de pé. Os bens da dinastia foram confiscados e os parentes restantes de Ibn Tulun foram acorrentados e levados como prisioneiros para Bagdá. ${ }^{57}$

Cf. SUNDELIN, L. Op. cit., p. 431 e LANE-POOLE, S. Op. cit., p. 2144.

SEARS, S. Tulunids. In: MERI, Joseph (Ed.). Op. cit., v. 2, p. 834-835.

LO JACONO, C. Op. cit., p. 70 e LANE-POOLE, S. Op. cit. p. 2144.

SHALABY, A. Op. cit., p. 246; SUNDELIN, L. Op. cit. 


\section{Conclusões}

O primeiro emirado autônomo do Egito pôde ser facilmente destruído no momento em que a dinastia dirigente - combalida pelas disputas em seu interior - perdeu apoio de uma parcela importante dos comandantes militares. Reproduzindo literalmente os juízos dos cronistas medievais, Philip Hitti observou que Ahmad "agiu com independência e energicamente", porém, "seus sucessores incompetentes locupletaram-se na luxúria" e levaram o governo ao colapso. ${ }^{58}$ Por sua vez, também se atendo ao texto das fontes, Stanley Lane-Poole, um dos primeiros historiadores modernos do assunto e, ainda hoje, uma referência fundamental, fez recair a responsabilidade pelo declínio sobre as gastanças do sucessor do fundador, mas acrescentou que, após a morte dele, seguiram-se anos de anarquia, durante os quais "as tropas turcas fizeram o que quiseram com os dois filhos de Khumarawayh". ${ }^{59}$ Menciono essas passagens para observar que, desde o século XIX até bem recentemente, essa forma de avaliar as causas do declínio tulúnida - decadência dos costumes associada à manipulação de emires muito jovens pelos chefes militares turcos - esteve amplamente espalhada pela historiografia orientalista. Ela está prenhe de premissas moralizantes sobre o bom e austero exercício da autoridade e, nesse aspecto, dá continuidade a uma longa tradição de juízos sobre os supostos desvarios indecorosos dos governantes orientais que remonta, no mínimo, ao que diziam os gregos clássicos a respeito dos persas. ${ }^{60}$

Todavia, embora enviesada, essa explicação dos processos não deixa de conter elementos bastante sugestivos para se refletir sobre fatores políticos de longa duração na história do Egito. Encerro esse artigo tocando bem rapidamente no mais evidente deles: a forma de composição dos quadros burocráticos e militares que assessoravam as elites dirigentes, em particular o emprego de soldados-escravos, principalmente, mas não somente, de origem asiática (turcos, caucasianos). Desde o século IX, quando o primeiro deles foi enviado para administrar o país, até as duas últimas décadas do século XIX, época em que todas as formas de escravidão foram proibidas, esse mecanismo organizacional foi profusamente empregado no Egito.

58 HITTI, P. K. The Near East in History, p. 302.

59 LANE-POOLE, S. Op. cit., p. 2144.

60 Cf. as sínteses cômodas de BRIANT, P. Fastes et splendeurs de la cour de Perse. L'Histoire, v. 208, p. 60-67, mars 1997 e LENFANT, D. Les Barbares ont un pays: la Perse. L'Histoire, v. 232, p. 50-51, mai 1999. 
Ele foi mitigado durante o califado dos Fatímidas, que fizeram largo uso de tropas recrutadas entre as tribos berberes e beduínas. ${ }^{61}$ Mas esse período constituiu um interregno que não chegou a alterar um esquema que atingiu o auge com o Reino dos Mamelucos, entre 1250 e 1517, e se reproduziu ao longo da época em que o Egito foi uma província do Império Otomano até finais do século XIX. ${ }^{62} \mathrm{~A}$ partir do século XVIII, porém, a procedência dos soldados-escravos foi modificada. Muitos continuaram chegando da Ásia, mas a fonte principal passou a ser, cada vez mais, a própria África. ${ }^{63}$

Uso a expressão mecanismo organizacional para enfatizar e sugerir a possibilidade de um tratamento estrutural-funcional das oligarquias de soldados-escravos (mamluks). No caso egípcio, ele foi empregado pela primeira vez durante o emirado de Ahmad Ibn Tulun. Os militares se constituíram como oligarquia, mas não definiram um procedimento sucessório diferente daquele que vigorava no centro do califado, baseado na transmissão intrafamiliar do governo. Uma forma alternativa, agora fundada em disputas no interior da elite dirigente sem que se considerasse a hereditariedade como fator nuclear, foi adotada no Reino dos Mamelucos. Mas isso aconteceu três séculos e meio depois. ${ }^{64}$ Assim, a derrocada da dinastia dos Tulúnidas não foi contestada nem por alguém da família, nem pelos militares turcos, que não hesitaram em debandar para o lado vencedor. Quem agiu contra a restauração abássida foram as camadas populares das cidades. Elas não demoraram a ser submetidas, como em um passado não muito distante, ao arbítrio dos wali enviados por Bagdá. De 905 a 935, quando uma nova tentativa de construção de um emirado autônomo foi empreendida no Egito por uma dinastia turca conhecida como os Ikhshidids, foram anos de motins, de quedas abruptas de governantes, de disputas violentas entre segmentos da elite dirigente e de dificuldades tremendas para resistir ao assédio crescente dos guerreiros nômades do deserto. Isso, porém, é outra história.

Recebido em maio de 2012. Aprovado em setembro de 2013.

61 Sobre os Fatímidas, GOLDSCHMIDT, Jr., A. A Brief History of Egypt, p. 43-47 e LANDO, F. Medio Oriente, p. 125-129.

62 GOLDSCHMIDT, Jr., A. A Brief History of Egypt, p. 49-89.

63 BACHARACH, J. African military slaves in the Muslim Middle East. BlackPast.org: Remembered and Reclaimed, s/d (www.blackpast.org).

64 HOLT, P. M. The Mamluk sultans, 1250-1517. History Today, v. 27, n. 11, November 1977, p. $719-725$. 